DOI:10.1515/mmr-2017-0012

Original article

\title{
DETECTION OF PLACENTAL CHROMOSOMAL ABERRATIONS IN EARLY SPONTANEOUS ABORTIONSIN CORRELATION WITH THE HISTOLOGIC FINDINGS
}

\section{ДЕТЕКЦИЈА НА ХРОМОЗОМСКИ АБНОРМАЛНОСТИ НА ПОСТЕЛКАТА КАЈ РАНИТЕ СПОНТАНИ АБОРТУСИ ВО КОРЕЛАЦИЈА СО ХИСТОЛОШКИТЕ ПРОМЕНИ}

\author{
Katerina Kubelka-Sabit ${ }^{1}$, Gorgi Bozinovski ${ }^{2}$, Jasar Dzengis ${ }^{1}$, Vanja Filipovski ${ }^{1}$, Slobodan \\ Lazarevski ${ }^{1}$, Mitko Ivanovski ${ }^{1}$ and Dijana Plaseska-Karanfilska ${ }^{2}$ \\ ${ }^{1}$ Clinical Hospital Acibadem Sistina Skopje, ${ }^{2}$ Research Center for Genetic Engineering and Biotechnology \\ "Georgi D Efremov", Macedonian Academy of Sciences and Arts, Skopje, Republic of Macedonia
}

\begin{abstract}
Using a variety of molecular techniques, it has been established that loss of pregnancy occurs in one to two thirds of all fertilized embryosin the first trimester. In about $50 \%$ of the cases, chromosomal abnormalities are the cause of early spontaneous abortion. Several histological characteristicsof the placenta, such as presence of villous stromal cavitations, fetal erythrocytes, umbilical cord, fetal tissue,etc. are suggested as predictive factors for aneuploidy.

Two hundred and thirty one cases were analyzed in this prospective study, 50 cases were control artificial abortions and 181 cases were early spontaneous abortionsanalyzed in the period from May 2012 to December 2014. Standard histopathological analysis and molecular techniques based on polymerase chain reaction were used to analyze the samples.

Usingmolecular techniques, aneuploidy was detected in $53.1 \%$ of the samples. The most frequently detected aneuploidy was trisomy 16 , followed by trisomy 22 , 21, 14 and 18. The molecular analysis also enabled distinction of maternal and paternal origin of the alleles. In the histopathological sample analysis, binary logistic regression analysis indicated the presence of trophoblastic proliferation $(\mathrm{p}=0.008)$ and the absence of fetal red blood cells $(p=0.001)$ as independent significant factors in the prediction of aneuploidy in early spontaneous abortion.

In conclusion, our results show that clinically relevant and accurate diagnosis of early spontaneous abortion which can determine its causecan only be achieved bya controlled process of selection of the material, histopathological and molecular analysis, followed bya necessary correlation of these results.
\end{abstract}

Keywords: aneuploidy, histopathological analysis,

Correspondence to: Katerina Kubelka-Sabit, Clinical Hospital AcibademSistina, Skupi 5a, 1000 Skopje, R. Macedonia; Phone: +389 703653 38; Fax: +38923099 599; E-mail:catkubelka@yahoo.co.uk; katerina.kubelka@acibademsistina.mk miscarriage, molecular analysis

\section{Апстракт}

Со употреба на различни молекуларни техники е утврдено дека во првиот триместар настанува губење на дури една до две третини од сите фертилизирани ембриони. Во околу $50 \%$ од случаите, причина за ран спонтан абортус се хромозомските абнормалности. Како предвидувачки фактор за анеуплоидија кај постелката се користат неколку хистолошки карактеристики, како вилозни празнини, нуклеирани еритроцити, папочна врвка, фетално ткиво и сл.

Во проспективната студија беа анализирани 231 случај, од кои 50 случаи на намерен абортус и 181 случај на ран спонтан абортус, обработени во периодот од мај 2012 година до декември 2014 година. За анализа на примероците е употребена стандардна хистопатолошка анализа и молекуларни техники, базирани на полимераза верижна реакција. Со употреба на молекуларните техники беше детектирана анеуплоидија кај 53,1\% од примероците. Најчесто детектирана анеуплоидија беше трисомија 16 , следена со трисомија 22, 21, 14 и 18 . Исто така, молекуларните анализи овозможија разликување на алелите по потекло од мајката и од таткото.

При хистоморфолошката анализа на примероците, бинарната логистичка регресиска анализа го посочи присуството на трофобластна пролиферација $(\mathrm{p}=0.008)$ и отсуството на фетални еритроцити $(\mathrm{p}=0.001)$ како независни сигнификантни фактори во предикција на анеуплоидија кај раните спонтани абортуси.

Како заклучок-добиените резултати покажаа дека за точна и клинички релевантна дијагноза на спонтан абортус, односно утврдување на причината за негово настанување е потребно јасно дефинирање на процесот на селекција и обработка на материјалот, преку хистопатолошка и молекуларна анализа, 
до неопходната меѓусебна корелација на резултатите од овие анализи.

Клучни зборови: анеуплоидија, молекуларна анализа, спонтан абортус, хистопатолошка анализа

\section{Introduction}

In 1977, the World Health Organization defined abortion as an extraction or expulsionof a fetus weighing 500 grams or less. Today, abortion is defined as a spontaneous loss of pregnancy before the fetus is able to survive outside the womb. The term miscarriage is used for many complications of early pregnancy. Therefore, in 2005 the European Society of Human Reproduction and Embryology (ESHRE) introduced a revised terminology that refers to early miscarriage. Thus, loss of pregnancy after a positive urine test for $\beta \mathrm{HCG}(\beta$ Human Chorionic Gonadotropin) or elevated serum $\beta \mathrm{HCG}$ before ultrasound or histological verification of pregnancy is defined as a biochemical abortion. Such abortions usually occur before the third or fourth, but certainly before the sixth week of gestation. It is thought that $30 \%$ of human concepts are lost in the preimplantation period, while another $30 \%$ are destroyed after implantation, but before the delayed menstrual period [1].

The clinical term miscarriage is used when there is an ultrasonic or histological confirmation of intrauterine pregnancy. Clinical miscarriage can be further divided into early clinical miscarriage, which occurs before the twelfth week of gestation or late clinical miscarriage, which occurs between the twentieth and twenty-first week of pregnancy.

The incidence of early clinical miscarriage is about $15 \%$, with considerable variation depending on maternal age [2,3]. For women aged 20 to 24 years, the incidence of early clinical miscarriage is $10 \%$, but it rises to $51 \%$ among women aged 40 to 44 years [4].

Late pregnancy losses between 12 and 21 weeks are less common, with an incidence rate of $4 \%$ [4].

Unlike sporadic miscarriages, recurrent miscarriages have significantly lower incidence rate and if only clinical miscarriages are considered, the prevalence is $0.8 \%$ to $1.4 \%$. Although clear criteria for the definition of recurrent miscarriage are not yet established, ESHRE recommends that recurrent miscarriage is the one preceded by two or more consecutive pregnancy losses before the 22nd week of gestation [4]. According to this definition, one out of every three women hasexperienced recurrent miscarriages [5].

In most medical facilities in the world, products of conception from spontaneous abortions are sent for routine histopathological analysis. This analysis is intended primarily to confirm the presence of intrauterine pregnancy. It is also important torule out a possible molar pregnancy, which increases the risk of persistent trophoblastic disease or choriocarcinoma. Also, using additional molecular diagnostic techniques such as flow cytometry, in situ hybridization and polymerase chain reaction, it is possible to detect aneuploidy or to accurately determine the type of molar pregnancy [6]. Chromosomal abnormalities are common in early spontaneous abortions [7,8]. According to some studies, the incidence of aneuploid zygotes in general is around $40 \%$ [8]. Aneuploidy rarely occurs in successful pregnancies $(0.6 \%)$, but is far more common in miscarriages in the first trimester, when it occurs in approximately $50-60 \%$ of cases $[9,10]$. It is thought that chromosomally abnormal embryos suffer adverse selection in the first few weeks of life, with mechanisms likely involving implantation and placental development (so-called fetal-maternal interactions). The frequency and type of chromosomal abnormalities that occur in spontaneous abortions vary with gestational age of the fetus and maternal age. Loss of pregnancy that occurs in the first weeks of pregnancy is characterized by a wide range of unusual aneuploidies, whereas loss of pregnancy later in the gestation is usually a consequence of aneuploidy typically found in live births, such as trisomy 21,18 or 13 [11].

Fetal aneuploidies are found in $90 \%$ of cases with pregnancy loss between the first and sixth weeks, while about $50 \%$ of pregnancy losses are due to aneuploidy between the eighth and eleventh week of gestation. The proportion of abortions that are due to aneuploidy decreases with gestational age and isaround 6 to $12 \%$ after the twelfthweek of gestation [11]. When a heart rate is detected by ultrasound examination, the risk of aneuploidy is thought to be less than 5\% [5]. The frequency of sporadic pregnancy loss and all fetal chromosomal abnormalities increases with maternal age [12]. The aim of the study was to detect aneuploidies in early spontaneous abortions. Also, to identify the subtle histological changes of the placenta that would eventually suggest presence of aneploidy.

\section{Material and methods}

This study wasdesigned as a prospective one. It included a total of 181 consecutive cases of early miscarriage diagnosed in the period from May 2012 to December 2014. Additional control group included 50 cases of early artificial abortions.

The study cases and the control cases were analyzedand evaluated in the Laboratory for histopathology and cytology at the "Acibadem Sistina" Hospital and the Research Centre for Genetic Engineering and Biotechnology "George D. Efremov" at the Macedonian Academy of Sciences and Arts in Skopje.

All products of conception werefirst analyzed macroscopically fresh (non-fixed) (Figure 1). Then, $500 \mathrm{~mm}^{3}$ of placental tissue for molecular detection of chromo- 
somal abnormalities and $500-1000 \mathrm{~mm}^{3}$ of decidual tissue for comparative genetic analysis of the motherwere selected and frozen in liquid nitrogen for further molecular diagnostics.

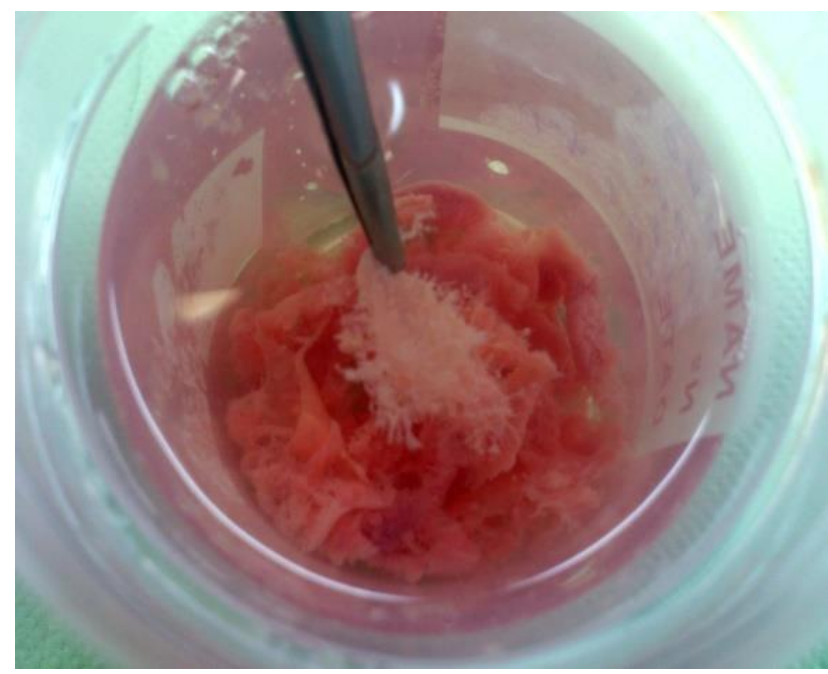

Fig. 1. Macroscopic selection of placental and decidual tissue

In the next step, additional representative samples of placental and decidual tissue were selected and fixed for 24 hours in $10 \%$ neutral buffered formalin. After wards, the samples were processed in a tissue processor, using a standard tissue processing procedure.

The paraffin tissue blocks were cut in $4 \mu$ thin sections, which were deparaffinized, rehydrated and stained with hematoxylin and eosin.

Microscopic analysis of the placental tissue was performed according to the criteria described below. This analysis was performed on 143 samples of spontaneous abortions (two cases were excluded from this analysis due to lack of adequate quantity of placental tissue) and 34 samples from the control group. A standard light microscope Leica DM2500 equipped with 4, 10, 20, 40 and 100 times objectives was used for this analysis.

The following characteristics of the placental tissue were analyzed: villous contours, appearance of the villous stroma (mucoid or hydropic change, cavitations), presence of fetal erythrocytes, trophoblastic hyperplasia and trophoblastic stromal inclusions.

Molecular analysis of the tissue was performed in 145 samples from the study group and in 34 samples from the control group. The reasons for exclusion of the rest of the samples are given in Table 1 .

A small volume of about $2-3 \mathrm{~mm} 3$ of the frozen tissue samples was transferred in $1.5 \mathrm{ml}$ sterile tube. Samples were washed with $1 \mathrm{ml} 1 \mathrm{xPBS}$ (phosphate buffer). Then, the samples were centrifuged at $12000 \mathrm{rpm}$ at $4^{\circ} \mathrm{C}$ for 5 minutes. The resulting sludge was digested in a waterbath at $56^{\circ} \mathrm{C}$ in $500 \mu \mathrm{l}$ digestion solution containing $20 \mu \mathrm{l}$ proteinase $\mathrm{K}(10 \mathrm{mg} / \mathrm{ml})$. After 2 hours (time required for digestion), DNA (deoxyribonucleic acid) extraction was performed using a mixture of equal amounts of phenol $(250 \mu \mathrm{l})$ and chloroform $(250 \mu \mathrm{l})$. The solutions were mixed together for 5 minutes; then the mixturewas centrifuged 5 minutes at $12000 \mathrm{rpm}$. After spinning, the resulting upper liquid phase was transferred to a $1.5 \mathrm{ml}$ sterile tube and the cycle was repeated. By adding $1 \mathrm{ml}$ of $96 \%$ ethanol, the DNA was precipitated and then centrifuged 30 minutes, at $12000 \mathrm{rpm}$ at $4^{\circ} \mathrm{C}$. The samples were rinsed with $70 \%$ ethanol and centrifuged at $12000 \mathrm{rpm}$ for additional 5 minutes. The excess of ethanol was removed and DNA was left for few minutes at room temperature until complete evaporation of the ethanol. Depending on the amount of DNA obtained, it was further dissolves in $50 \mu$ sterile water.

In order to determine the possible presence of chromosomal aneuploidy in the placental tissue, QF-PCR (Quantitative Fluorescent Polymerase Chain Reaction) analysis was performed on ABI-PRISM 3100 and 3500 genetic analyzers. In this PCR method, one of the primers used for amplification is fluorescently labeled. The obtained products are fluorescent, therefore apart from the quailtative characteristics of the PCR amplification (amplicon size), the quantity of the amplicons in the amplified genome can also be determined. The analysis is performed in a multiplex PCR reaction analyzing fourshort tandem repeats (STR) on chromosomes 18 (D18S535, D18S391, D18S390 and D18S386), 21 (D21S1435, D21S1446, D21S1411 and D21S1414), 13 (D13S631, D13S305, D13S258 and D13S1817), two on the X chromosome (DXS6803 and HPRT), and amelogenin locus (AMXS) to determine the gender. These markers are chosen to be trinucleotide repeats and have higher heterozygosity to be informative. PCR reactions were performed in a mixture with a total volume of $20 \mu \mathrm{l}$, containing 1xPCR buffer, 1.5-2.0 mM MgCl2, 200 microns ofdNTP, $25 \mathrm{pM}$ of the respective primers (direct and reverse), 1U AmpliTaq Gold DNA polymerase (Applied Biosystems) and $0.10 .5 \mu \mathrm{g}$ DNA. PCR reaction was carried out on Thermal Cycler (Applied Biosystems 2720) under the following conditions: initial denaturation at $95^{\circ} \mathrm{C}$ for $10 \mathrm{~min}$ with activated AmpliTaq Gold polymerase, followed by 28 cycles of denaturation at $95^{\circ} \mathrm{C}$, annealing at $58^{\circ} \mathrm{C}$ for $1 \mathrm{~min}$ and elongation at $72{ }^{\circ} \mathrm{C}$ for $1 \mathrm{~min}$ and 30 seconds.

If chromosomal aneuploidies were not detected with the QF-PCR analysis, the subtelomeric regions on all chromosomes were further analyzed using the MLPA (Multiplex Ligation Probe Amplification) method. This method is performed using two kits: SALSA MLPA kit P036-D Human Telomere-3 and SALSA MLPA P070-D Human Telomere-5 (MRC Holland, Amsterdam). These two kits contain 45 different oligonucleotide sequences from different subtelomeric regions of the short and long arms of all autosomal and sex chromosomes. The MLPA method allows simultaneous amplification of all 45 target DNA 
sequences. Each MLPAprobe contains short specific sequences (22-43 nucleotides) and auniversal direct and reverse PCR primer. In order to distinguish the amplified products, probes also contain non-hybridizing sequence of variable length (19-364 nucleotides). The hybridization reaction is performed overnight and the target DNA sequences connect with the hybriddizing probes in a ligation reaction. Ligated products are further amplified in a PCR reaction. The relative quantity of each PCRproduct is proportional to the copy numbers of the target sequence. The relative amount of each PCR product is proportional to the number of copies of the target sequence. PCR products of different sizes are separated by automated capillary electrophoresis. The hybridization reactions, ligation and amplification were performed on ABI 9800 Thermal Cycler (Applied Biosystems, USA).

The statistical analysis was performed using statistical program SPSS forWindows, 17.

\section{Results}

Chromosomal aberrations were significantly more often detected in the study group of early spontaneous abortions than in the control groupof artificial abortions $(\mathrm{p}=0.000001)$. In fact, aneuploidy was detected in only $5.9 \%$ of the control cases $(2 / 34 \%)$, whereas in $53.1 \%$ of the studycases (77/145). Results from the molecular analysis of both groups are shown in detail in Table 1.

The most commonly detected chromosomal abnormality was trisomy 16 , which was found in $14.5 \%$ of cases. Theageofthepatients did not influence the occurrence of any of the chromosomal abnormalities ( $p>0.05)$. Patients with trisomy 16 , trisomy 18 , trisomy 21 , trisomy 22 and Turnersyndrome were insignificantly older than patients without these abnormalities $(38.0 \pm 4.2$ vs $36.16 \pm 5.7 ; 40.4 \pm 4.2$ vs $36.26 \pm 5.6 ; 37.0 \pm 6.4$ vs $36.36 \pm 5.5$; $37.69 \pm 4.4$ vs $36.27 \pm 5.63$ and $36.67 \pm 5.7$ vs $36.37 \pm 5.6$, consequently).
Histological analysis was performed in 143 cases from the study group and 34 cases from the control group. These results were compared with the molecular test results.

Statistically significant association was found between the presence of trophoblastic hyperplasia on the villous surface and aneuploidy $(\mathrm{p}=0.0004)$. Trophoblastic hyperplasia was present in 32(47.76\%) samples with nor-

Table 1. Chromosomal abnormalities in the study group and the control group

\begin{tabular}{lcc}
\hline & $\begin{array}{c}\text { Control group } \\
\mathbf{n = 5 0}\end{array}$ & $\begin{array}{c}\text { Study group } \\
\mathbf{n = 1 8 1}\end{array}$ \\
\hline Chromosomal abnormalityn $\mathbf{( \% )}$ & \\
Normal & $32(94.12)$ & $68(46.90)$ \\
Trisomy 2 & 0 & $1(0.68)$ \\
Trisomy 4 & 0 & $1(0.68)$ \\
Trisomy 6 & 0 & $1(0.68)$ \\
Trisomy 7 & 0 & $2(1.38)$ \\
Trisomy 8 & 0 & $3(2.07)$ \\
Trisomy 9 & 0 & $1(0.68)$ \\
Trisomy 10 & 0 & $1(0.68)$ \\
Trisomy 14 & 0 & $6(4.14)$ \\
Trisomy 15 & 0 & $3(2.07)$ \\
Trisomy 16 & $1(2.94)$ & $21(14.48)$ \\
Trisomy 18 & 0 & $5(3.45)$ \\
Trisomy 14/Trisomy 20 & 0 & $1(0.68)$ \\
Trisomy 21 & 0 & $5(3.45)$ \\
Trisomy 22 & 0 & $13(8,97)$ \\
Triploidy & $1(2.94)$ & $5(3.45)$ \\
Monosomy 21 & 0 & $1(0.68)$ \\
Turner Sy & 0 & $6(4.14)$ \\
3p deletion & 0 & $1(0.68)$ \\
Total & $34(68)$ & $145(80.11)$ \\
Inadequate for molecular analysisn $(\%)$ & \\
Identical maternal and & $3(18.75)$ & $22(61.1)$ \\
fetal profile & 0 & $2(5.56)$ \\
Poor quality DNA & $13(81.25)$ & $12(33.33)$ \\
DNA isolation not & $16(32)$ & $36(19.89)$ \\
possible & & \\
\hline Total & 0 & \\
\hline
\end{tabular}

mal genotype and in 58(76.32\%) samples with aneuploidy. There was no significant difference in the type of trophoblastic proliferation, since both focal and diffuse trophoblastic proliferation were more often present in aneuploid cases $(\mathrm{p}=0.79)$.

Table 2. Multivariate analysis of predictive histologic factors associated with early spontaneous abortions

\begin{tabular}{lcc}
\multicolumn{1}{c}{ Variable } & $\begin{array}{c}\text { OR } \\
\text { 95\% CI for OR }\end{array}$ & p value \\
\hline $\begin{array}{l}\text { Presence vs absence of trophoblastic } \\
\text { proliferation }\end{array}$ & $2.956(1.322-6.609)$ & $0.008^{* *}$ \\
$\begin{array}{l}\text { Presence vs absence of trophoblastic } \\
\text { stromal inclusions }\end{array}$ & $0.699(0.325-1.506)$ & 0.361 \\
$\begin{array}{l}\text { Presence vs absence of irregular villous } \\
\text { contours }\end{array}$ & $1.86(0.874-3.957)$ & 0.008 \\
$\begin{array}{l}\text { Presence vs absence of stromal cavitations } \\
\text { Hydropic vs mucoidvillousstromal change }\end{array}$ & $0.948(0.192-4.681)$ & 0.948 \\
$\begin{array}{l}\text { Pronounced edema vs mucoid villous } \\
\text { stromal change }\end{array}$ & $2.142(0.781-5.875)$ & 0.139 \\
Presence vs absence offetal erythrocytes & $0.124(0.68-9.337)$ & 0.167 \\
\hline$* *$ p $<0.01$ & & $0.001 * *$ \\
\hline
\end{tabular}


The presence of fetal erythrocytes was more often seen in aneuploid than in euploidplacentas $(64.47 \%$ vs $59.7 \%)$. However, this difference was not statistically significant $(\mathrm{p}=0.65)$.

Many nucleated red blood cells were significantly more often detected in the villous vasculature of euploid placentas compared to aneuploid ones $(8.96 \%$ vs $1.82 \%$, $\mathrm{p}=0.042$ ).

Binary logistic regression analysis was used to determine the independent morphologic characteristics as predictors in early spontaneous abortions. Presence of villous trophoblastic hyperplasia $(\mathrm{p}=0.008)$ and fetal erythrocytes $(\mathrm{p}=0.001)$ were found to be independent significant predicting factors (Table 2).

All other histological parameters, such as villous contours, villous vascularity or presence of trophoblastic stromal inclusions did not show any significant variations between euploid and aneuploid placentas (Figure 2).

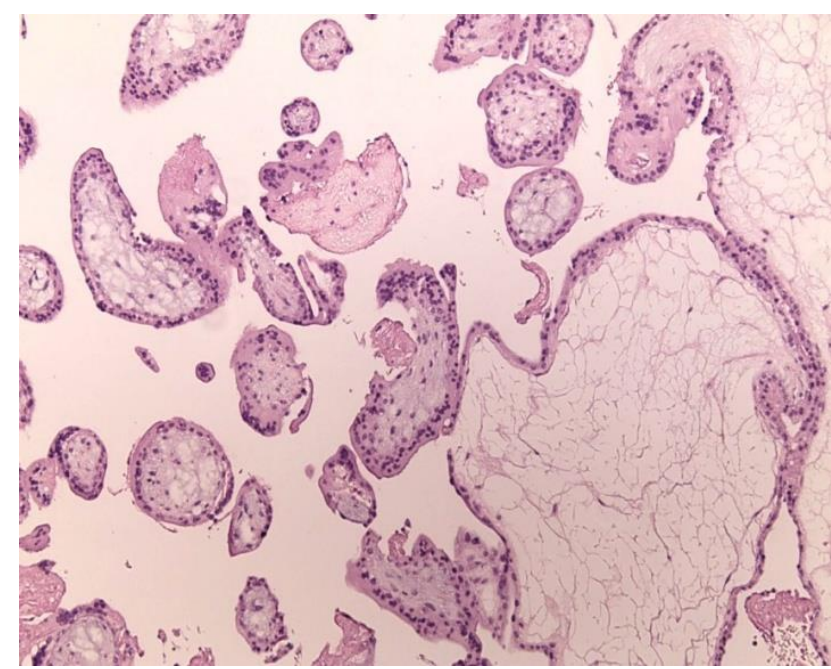

Fig. 2. Microscopic appearance of the placental villi in early spontaneous abortions (hematoxylin and eosin, x10)

\section{Discussion}

Placental role in pregnancy loss is not yet clear. Several authors suggest that aneuploidplacentas in early miscarriages have abnormal histology [13-15]. According to Genest et al. (1995), five histological features of the placenta can be used as predictive factors for abnormal karyotype: villous cavitation, fetal erythrocytes, abnormalities of amniotic membrane, presence of umbilical cord and presence of fetal tissue [14]. These authors suggest that villous dysmorphic features and presence of cystic cavities in the villous stroma are associated with triploidy while four characteristics (villous hydrops, absence of umbilical cord and fetal tissueand absence of fetal erythrocytes) are associated with trisomy [14].

In our study, only the presence of trophoblastic hyperplasia and paucity of fetal erythrocytes correlated with placental aneuploidy. Fetal erythrocytes in the villous vasculature in our study were more scarce in spontaneous abortions (62\%) compared to artificial abortions $(91 \%)$. There was also a significant difference in the presence of fetal red blood cells between euploid and aneuploid cases. In fact, according to the literature, fetal red blood cells are present mostly in normal pregnancy or partial molar pregnancy, while they are absent or present in significantly lower number in aneuploid placentas or complete molar pregnancy [14]. Regarding the findings of irregular villous contours, we did not find significant difference between euploid and aneuploid cases, nor between the control and study group. According to the literature, villous surface contours in aneuploid placentas should be irregular, jagged, unlike the smooth convex surface of euploid villi $[14,16]$. However, placental morphology in early pregnancy is not only influenced by karyotype, but also by gestational age and degenerative changes that are a consequence of intrauterine retention of a dead fetus. These degenerative changes are usually presented with stromal fibrosis, hypovascularization, stromal edema, attenuation of trophoblasts etc. [21]. On the other hand, the morphological changes of aneuploid placentas are very similar [22]. Other studies were also published in which authors found no significant correlation between the findings of chromosomal abnormality and histological changes in the placenta [16,21].

According to Jauniaux and Burton (2005), the main histological examination criteria for early pregnancy loss should be: villous contours, development oftrophoblasts (assessment of the degree of hyperplasia or hypoplasia), appearance of the villous stroma (degree of edema and fibrosis), development of the fetal circulation and intervillous fibrin deposition. According to these authors, so called villous type 1 tissuewith pronounced villous stromal edema is frequently associated with chromosomal abnormalities [16].

According to other authors, trophoblastic stromal inclusions are often associated with chromosomal abnormalities or genetic disorders without apparent chromosomal abnormality. However, longer periods of intrauterine death (3-8 weeks) should be taken into account,since the appearance of such artifacts can reduce the predictive value of placental histology in identifying aneuploid early spontaneous abortions [16]. We detected significantly more chromosomal abnormalities in cases of spontaneous abortions (53\%) in comparison to the artificial ones (6\%). These results correlate with other results reported in the literature. Namely, it is considered that chromosomal abnormalities can be found in about half of the early miscarriage cases [14]. On the other hand, when losses of pregnancy in the second or third trimester of pregnancy had been analyzed, chromosomal abnormalities werefound in only about $20 \%$ of cases [16]. The rate of aneuploidy 
inartificial abortions is expected to range between 2.5 to $4.5 \%$ [17], which is in concordance with our results. Most fetal chromosomal abnormalities are numeric $(86 \%)$, while small percentage are structural abnormalities $(6 \%)$ or other genetic mechanisms, including chromosomal mosaicism (8\%) [17]. It not yet established whether chromosomal aberrations are more common in recurrent miscarriages, but it has been noted that around $50 \%$ of abortions in these women had chromosomal abnormalities [17]. Carp et al. (2001) published an incidence of $29 \%$ among women with three or more spontaneous abortions [18]. Ogasawara et al. (2000), however have shown that, as the number of abortions increases, the incidence of chromosomal aberrations is reduced [19]. The risk of recurrence of numerical abnormalities in subsequent pregnancies is small, so according to some authors karyotyping of fetal tissue in all cases of abortion is not considered an effective method in daily practice [17]. However, some authors routinely perform karyotyping or genotyping of fetal tissue from spontaneous abortions, since the discovery of chromosomal abnormalities in the fetus allow plausible explanation for the loss to the anxious couples. Macroscopic analysis is acommonly used selection method in pathology laboratories. Trained and experienced medical staff can easily recognize fragments of placenta and decidual tissue. But if products of conception are scarce, mixed with large amount of blood, the selection of adequate material for analysis can be significantly impaired. In many institutions worldwide, laser microdissection is method of choice for selection of placental fragments for further molecular analysis. However, according to our results, macroscopic tissue selection method, especially if trained pathologist is directly involved in the selection process, is simple, inexpensive and less time consuming method. Of course, experience is of utmost importance. Thus, during the initial selection of the first 50 samples, the failure rate of obtaining a good quality sample ranged up to $36 \%$. But in the last 100 samples, in which the selection of tissue samples was carried out exclusively by an experienced pathologist, the rate of inadequate samples for molecular analysis was reduced to just $5 \%$. This method of selection of material for genetic analysis by freezing fresh tissue is also used by other researchers such as Kokawaet al. (1998) [20].

There are several methods used for detection of numerical chromosomal abnormalities in spontaneous abortions. One is standard cytogenetic evaluation of tissue from spontaneous abortions. According to the literature, this method has certain limitations. Above all, vital tissue is mandatory, which may be a problem in cases with longer intrauterine retention of a dead fetus [23]. There is also a significant risk of contamination with vital decidual tissue from the mother, which can possibly give normal female karyotype originating from the mother (30-40\% of cases) [24,25], not the fetus. In addition, there is a high risk of bacterial contamination [14,26]. For example, Diego-Alvarez et al. (2007) investigated a total of 517 samples of early miscarriage and analyzed them by a conventional cytogenetic karyotyping. Successful karyotyping was performed in only 321 cases, i.e.in about $60 \%$ of cases [27]. On the other hand, the advantage of conventional cytogenetic analysis is the ability to detect structural rearrangements, which although rare, could explain the cause of early miscarriage in 4-8\% of cases [14].

Fluorescentin situ hybridization (FISH) allows rapid determination of aneuploidy. Several studies have shown that FISH is an effective and rapid technique for the diagnosis of numerical aberrations in amniocytes with significantly lower costs than traditional karyotyping [17,28]. Namely, all other molecular techniques such as MLPA, QF-PCR and array-CGH (Comparative Genomic Hybridization) have a definite advantage over conventional karyotyping. This refers to lower failure rate, shorter analysis time and significantly higher resolution [24,29]. Using FISH and QF-PCR, few chromosomes can be analyzed in one reaction, while MLPA and array-CGH methods can analyze copy number variations in 48 regions of the genome in a single reaction.

In this study we used two molecular methods to detect aneuploidy in placentas. TheQF-PCR method is based on amplification of chromosome-specific repetitive DNA sequences, so called STR (Short Tandem Repeats). These sequences are stable and polymorphic; they vary in length in different individuals, depending on the number of tri-, tetra- or penta-nucleotiderepetitions. The sample DNA was amplified in a PCR reaction using fluorescent primers. Thus, PCR products can be visualized and quantified as a peak of respective repetitive sequences of varying length. When DNA from normal heterozygous individual is amplified (whose DNA contains alleles of different length), two peaks in a zone are expected to be seen. When DNA from individuals who have certain trisomy isamplified, three peaks (three alleles), ortwo peaks (two alleles), one of which will be two times wider than the other, will appear in the relevant area [30].

If excessive or absent signal (or abnormal ratio) of a marker is found in an otherwise normal multiplex reaction, this could be due to fetal constitutional duplication or deletion of a chromosomal segment where the appropriate marker is located. In such cases, it is recommended to test the parents and retest the neighboring markers in order to identify the size of the alleged duplication or deletion [30].

Another very important advantage of the QF-PCR method is its ability to detectcontamination with maternal DNA. This property presents a significant advantage over FISH method for example, which can not distinguish contamination with maternal DNA in normal female karyotype. Thus, in our study maternal DNA 
contamination was found in $12 \%$ of the samples in the study group. Of particular importance in the diagnosis of spontaneous abortion is the possibility of the QFPRC method to be performed on archival material, or tissue samples from paraffin blocks. The concordance of the QF-PCR results with karyotype, according to some authors is around 95\% [31].

Whenwe did not find any aneuploidy with the QFPCR method, subtelomeric regions of all chromosomes were further analyzed using MLPA analysis. When comparing MLPA with array-CGH, MLPA method is cheaper and provides reliable and efficient detection of chromosomal numerical aberrations and subtelomeric copy number variations. The success rate ranges up to $98 \%$ and according to the literature, the method shows concordance> $90 \%$ with the karyotype [24]. However, the MLPA method has some disadvantages. Thus, the number of copies in this analysis is compared with a haploid set of chromosomes, rendering detection of polyploidy, low-grade mosaicism, balanced translocation or maternal DNA contamination impossible [24].

In this study the most common abnormality detected was trisomy 16 , followed by trisomy 22, 21, 14 and 18 . Other authors also refer highest incidence of trisomy 16 in early spontaneous abortions [17,28], followed by trisomy 13, 18, 21 and 22 [17]. It is considered the most common trisomy in early miscarriages with an incidence of about $1.5 \%$ of all clinically recognized pregnancies. Most fetuses with trisomy 16 end in miscarriage between 8 to 15 weeks of pregnancy [32]. Chromosomal abnormalities are the cause of pregnancy loss in 50 to $80 \%$ of cases depending on maternal and gestational age at the time of pregnancy loss [5]. Turner syndrome is the most frequent chromosomal abnormallity of sex chromosomes, found in 20 to $25 \%$ of cytogenetically abnormal fetuses by some authors [33,34]. Triploidy and tetraploidy result from abnormal fertilization and are not compatible with life. Primary pathogennic mechanism in triploidy is fertilization of a normal haploid egg by two sperm cells [35], although other pathogenetic mechanisms may lead to triploidy. In our study, triploidy was detected in $3.5 \%$ of the cases. In conclusion, this study allowed clarification of the etiological causes of early spontaneous abortion ina large group of patients.Histopathological analysis alone could not predict aneuploidy in early spontaneous abortion. Therefore, in order to obtain a correct diagnosis valuable to the clinicians, products of conception from early spontaneous abortions should be submitted for histopathological analysis and molecular genotyping whenever possible.

Conflict of interest statement. None declared.

\section{References}

1. Jauniaux E, Kadri R, and Hustin J. Partial mole and triploidy: screening patients with first-trimester spontaneous abortion. Obstet Gynecol 1996; 88(4 Pt 1): 616-619.

2. Angiolucci M, et al. Association between different morphological types and abnormal karyotypes in early pregnancy loss. Ultrasound Obstet Gynecol 2011; 37(2): 219-225.

3. Coelho FF, et al. Detection of aneuploidies in spontaneous abortions by quantitative fluorescent PCR with short tandem repeat markers: a retrospective study. Genet Mol Res 2016; 15(3).

4. Larsen EC, et al. New insights into mechanisms behind miscarriage. BMC Med 2013; 11: 154.

5. Hyde KJ, and DJ. Schust, Genetic considerations in recurrent pregnancy loss. Cold Spring Harb Perspect Med 2015; 5(3): a023119.

6. Fram KM. Histological analysis of the products of conception following first trimester abortion at Jordan University Hospital. Eur J Obstet Gynecol Reprod Biol 2002; 105(2): 147-149.

7. Wu Z, et al. [Detection of chromosome aneuploidies in spontaneous abortion villus samples by quantitative fluorescence PCR]. Zhonghua Yi Xue Yi Chuan Xue Za Zhi, 2016; 33(2): 227-230.

8. Qumsiyeh MB, et al. Cytogenetics and mechanisms of spontaneous abortions: increased apoptosis and decreased cell proliferation in chromosomally abnormal villi. Cytogenet Cell Genet 2000; 88(3-4): p. 230-235.

9. Warburton D, et al. Does the karyotype of a spontaneous abortion predict the karyotype of a subsequent abortion? Evidence from 273 women with two karyotyped spontaneous abortions. Am J Hum Genet 1987; 41(3): 465-483.

10. Jacobs PA, et al. Trisomy 13 ascertained in a survey of spontaneous abortions. J Med Genet 1987; 24(12): 721-724.

11. Wapner RJ and Lewis D. Genetics and metabolic causes of stillbirth. Semin Perinatol 2002; 26(1): 70-74.

12. Munne S, et al. Embryo morphology, developmental rates, and maternal age are correlated with chromosome abnormalities. Fertil Steril 1995; 64(2): 382-391.

13. Salafia C, et al. Placental and decidual histology in spontaneous abortion: detailed description and correlations with chromosome number. Obstet Gynecol 1993; 82(2): 295-303.

14. Genest DR, et al. Fetoplacental histology as a predictor of karyotype: a controlled study of spontaneous first trimester abortions. Hum Pathol 1995; 26(2): 201-209.

15. Jindal $\mathrm{P}$, et al. Placental pathology of recurrent spontaneous abortion: the role of histopathological examination of products of conception in routine clinical practice: a mini review. Hum Reprod 2007; 22(2): 313-316.

16. Jauniaux E, and Burton GJ. Pathophysiology of histological changes in early pregnancy loss. Placenta 2005; 26(2-3): 114-123.

17. Fejgin MD, et al. Fluorescent in situ hybridization: an effective and less costly technique for genetic evaluation of products of conception in pregnancy losses. Acta Obstet Gynecol Scand 2005; 84(9): 860-863.

18. Carp H, et al. Karyotype of the abortus in recurrent miscarriage. Fertil Steril 2001; 75(4): 678-682.

19. Ogasawara M, et al. Embryonic karyotype of abortuses in relation to the number of previous miscarriages. Fertil Steril 2000; 73(2): 300-304.

20. Kokawa K, Shikone T, and Nakano R. Apoptosis in human chorionic villi and decidua during normal embryonic development and spontaneous abortion in the first trimester. Placenta 1998; 19(1): 21-26. 
21. Fukunaga M, et al. Is There a Correlation Between Histology and Karyotype in Early Spontaneous Abortion? International Journal of Surgical Pathology 1995; 2(4): 295-300.

22. Paul $\mathrm{M}$, et al. Early molar pregnancy: experience in a large abortion service. Contraception 2010; 81(2): 150-156.

23. Carp HJ, et al. Prognosis of subsequent pregnancies after recurrent spontaneous abortion in first trimester. $\mathrm{Br} \mathrm{Med} \mathrm{J}$ (Clin Res Ed) 1987; 295(6603): 925-926.

24. Saxena D, et al. Utility and limitations of multiplex ligation-dependent probe amplification technique in the detection of cytogenetic abnormalities in products of conception. J Postgrad Med 2016; 62(4): 239-241.

25. Cheng $\mathrm{HH}$, et al. Chromosome distribution of early miscarriages with present or absent embryos: female predominance. J Assist Reprod Genet 2014; 31(8): 1059-1064.

26. Wu $\mathrm{T}$, et al. Molecular cytogenetic analysis of early spontaneous abortions conceived from varying assisted reproductive technology procedures. Mol Cytogenet 2016; 9: 79.

27. Diego-Alvarez D, et al. MLPA as a screening method of aneuploidy and unbalanced chromosomal rearrangements in spontaneous miscarriages. Prenat Diagn 2007; 27(8): 765-771.

28. Lescoat $\mathrm{D}$, et al. Fluorescent in situ hybridization (FISH) on paraffin-embedded placental tissues as an adjunct for understanding the etiology of early spontaneous abortion. Prenat Diagn 2005; 25(4): 314-317.
29. McClelland LS, et al. Implementation and experience of an alternative QF-PCR and MLPA diagnostic strategy to detect chromosomal abnormalities in fetal and neonatal pathology samples. Pediatr Dev Pathol 2011; 14(6): 460-468.

30. Hulten MA, Dhanjal S, and Pertl B. Rapid and simple prenatal diagnosis of common chromosome disorders: advantages and disadvantages of the molecular methods FISH and QF-PCR. Reproduction 2003; 126(3): 279-297.

31. Zou G, et al. Quantitative fluorescent polymerase chain reaction to detect chromosomal anomalies in spontaneous abortion. Int J Gynaecol Obstet 2008; 103(3): 237-240.

32. Yong PJ, et al. Clinical aspects, prenatal diagnosis, and pathogenesis of trisomy 16 mosaicism. J Med Genet 2003; 40(3): 175-182.

33. Chaithra P, MSaCS. An Overview of Genetic and Molecular Factors Responsible for Recurrent Pregnancy Loss. Int J Hum Genet 2011; 11(4): 217-225.

34. Nagy B, et al. Detection of sex chromosome aneuploidies using quantitative fluorescent PCR in the Hungarian population. Clin Chim Acta 2015; 445: 2-6.

35. Zaragoza MV, et al. Parental origin and phenotype of triploidy in spontaneous abortions: predominance of diandry and association with the partial hydatidiform mole. Am J Hum Genet 2000; 66(6): 1807-1820. 